\title{
Discussion of Function of Church and State in Public Education in the U.S.
}

\author{
Fang Wang \\ College of Foreign Languages, Changchun University of Science and Technology, Changchun, China \\ Email: harmonywang@163.com
}

Received 9 July 2014; revised 26 August 2014; accepted 10 September 2014

Copyright (C) 2014 by author and Scientific Research Publishing Inc.

This work is licensed under the Creative Commons Attribution International License (CC BY). http://creativecommons.org/licenses/by/4.0/

c) (i) Open Access

\begin{abstract}
Religion in relation to public education has been a topic of keen interest in the U.S. It has two components: one deals with the theme of religious content in the curriculum and the other concerns fringe benefits to nonpublic schools. And, where the State stands, the decisions and measures made by the U.S. Supreme Court concern religious matters in public schools.
\end{abstract}

\section{Keywords}

\section{Religion, Education, State}

\section{Introduction}

In this section, an overview will show the relationship between organized religion and public education in two major ways: (1) the curriculum in the public school; (2) publicly-funded fringe benefits to nonpublic schools. The best means of indicating this interaction between religion and public education is to cite several representative U.S. Supreme Court decisions, which have had a profound impact upon both the public and private educational sectors over the last several decades.

The topic is an important one, especially in terms of the curriculum, because religious heritage is a legitimate part of the curriculum and must be dealt with academically and objectively. Fringe benefits to nonpublic schools are continually being considered, because many nonpublic school educators and parents believe they constitutionally deserve such benefits. On the other hand, many public school advocates believe that increased public aid to nonpublic schools is unconstitutional. Such aid will also financially hurt the public school because of a potential loss of students and tax dollars [1].

Religion is a difficult term to define to everyone's satisfaction, but a couple of characteristics give clarity. It involves: (1) a belief about the meaning of life; (2) a commitment by the individual and the group to this belief; (3) a system of moral practices resulting from a commitment to this belief; and (4) recognitions by the propo- 
nents of this belief that it is supreme or absolute. In terms of the public school curriculum, any instruction which deals with an organized system of beliefs, with pertinent ritual, with accompanying values, and with desired behavior will be considered the instruction about religion.

The role of the church in a generic sense has always been sensitive in relation to secular matters, especially to public education. In the colonial period, the schools were usually the handmaiden of a church-state relationship. There was little question in most localities about ties between the dominant church and the government which served its purposes. Schools were created in part to perpetuate the theistic goals of that particular relationship. Tolerance for minority view was practically absent in colonial America. Secondary schools and colonial colleges served as examples of how denominational preference helped to determine educational opportunity.

What the founding fathers has in mind when the first amendment was written was not so much a fear of European threats to their religious liberty as it was apprehension of the settlers themselves, who became as intolerant as the Europeans from whom they fled. Examples were rife in colonial America of independent thinkers who has met with dire hardships at the hands of colonists in control who held different religious beliefs. For instance, in Massachusetts Colony only members of the Puritan church could hold office or vote, and in Virginia, colonists had to pay fines if they missed Anglican Church services on Sunday morning or afternoon. Even in Pennsylvania, mistrust and intolerance were rampant because the various parochial schools were organized by different languages and religious views. Each ethnic sect was suspicious of the other, fearing loss of religious integrity if anyone thought of such a topic as tax support for schools.

By the late eighteenth century, three-fourths of the young states still had established ties between church and state. This frequently meant loss of individual religious freedom and forced taxation to a church which often did not represent the religious views of the person paying the tax. This undemocratic process led Thomas Jefferson to submit in 1779 in Virginia a bill to establish religious freedom, which he had hoped when passed would serve as a precedent for other soon-to-be states [2].

The bill was debated heatedly for six years before it became law in Virginia in 1785. This law served as an excellent example for other states to follow and also served as a model for the framers of the constitution. It is said that Jefferson valued his Bill for Establishing Religious Freedom second only to his Declaration of Independence.

It is easy to see the connection between the theme of this first clause of the First Amendment and that of Jefferson's bill for Establishing Religious Freedom in Virginia a few years earlier. The difficulty, however, in terms of universalizing this concept was that the thinking of the First Amendment applied to the Congress, not to the states. In other words, the U.S. Congress could not establish a national church and extract taxer from citizens to maintain it. Nor could it compel people to attend church services of any kind. The states were left to continue as they wished in church-state matters, especially concerning education. In fact, Massachusetts and Connecticut continued such a church-state relationship until the 1830s.

Jefferson himself thought that the first clause of the First Amendment created a "wall of separation" between church and state; however, it would take a long time to decide what that term meant in context of U.S. Supreme Court decisions, and certainly in many ways the wall of separation is still not clear. Additionally, the Fourteenth Amendment, ratified in 1868, was necessary to bring down to the state level all the privileges, guarantees, and immunities of the U.S. Constitution. Theoretically, no state could establish a church or require church attendance or restrict religious freedom. Supreme Court decisions would clarify the intent of the Constitution in relation to specific issues. In all the court cases of recent years, the First and Fourteenth Amendments are discussed in context of their purposes.

Between the ratification of the First Amendment (1791) and the Fourteenth Amendment (1868), educators were almost at a loss to cope with the challenge of the separation of church and state in educational matters [3]. Horace Mann, First State Secretary of Education in Massachusetts (1837), found quite a dilemma in this area. Mann was opposed to sectarian indoctrination in the public school partly because it served to divide or polarize people, yet he did not want the pendulum to swing to the other extreme of secularism [4]. He fought hard, consequently, to keep Bible-reading exercised in the public school. The problem, though, was aggravated because the Protestants subscribed to the King James Version of the Bible, and the Catholics supported the Douay Version. Unfortunately, there was no Annotated Revised Standard version yet on the market (as there is today), which would have been acceptable to both Catholics and Protestants. Also, had the Bible been more a tool to study about religion rather than a source for devotional exercises, the conflict would not have been so intense.

Simultaneous with Mann's insistence on the use of the King James Version of the Bible in the public schools, 
there occurred a flood of Irish-Catholic immigration to American shores. This Irish emigration to America reached its peak between 1845 and 1850, when over one million predominantly Irish Catholics left their homeland to seek opportunity in the United States. Whit such numbers from Ireland alone, American Catholic officials were worried about how the spiritual needs of Catholic children would be met in public schools, Consequently, in 1840 in Baltimore, for example, the Provincial Council of the Roman Catholic Church urged its priests to keep Catholic children Catholic by the avoidance of public school devotionals based on the King James Bible. The Church was adamantly opposed to Protestant devotional exercises in public schools.

Mann's attitude about the use of the Bible in public education was a thoughtful one, but it caused problems because there was no consensus about the use of the King James Version.

In addition to the problem of lack of consensus concerning the use of the King James Version of the Bible, the school commonly used the Scriptures during this era as devotional exercises, which tended to alienate nonProtestants. An anti-Catholic sentiment likewise erupted in many places across the country, due in part to the heavy influx of Irish Catholics in the 1840s. "Native American” groups for many reasons openly opposed the "foreign elements" in American society. Street riots, church burnings, and verbal abuse were all too common during this period. In New York, Archbishop John Hughes concluded that part of the remedy might be to enlarge the parochial school system to include all school-age Catholic children. A definite schism was developing between public and parochial schools, partly because the climate of the public school did not embrace minority views. A respect for religious diversity was not the attitude of the public schools in most places.

The U.S. Supreme Court is still grappling with the same problems; it believes that religious heritage must be a part of general education, but not as devotional exercises. Although many people want such exercises, the Court nevertheless has banned them thus far. Consequently, many believe that this kind of judicial neutrality has created a "religion of no religion," which in essence is a form of humanism. The issue has never been settled.

\section{Representative Supreme Court Decisions Affecting the Curriculum}

The constitution has meaning when the U.S. Supreme Court interprets it issue by issue. Several significant cases have been handed down by the Court in this century, which closely touch the curriculum of the public school. This process of interpretation is continual. Certainly the present decade is proving to be an active one for both the Court and the schools in regard to such things as Bible reading and prayer. In this section, an overview of representative cases is offered about what the public school can and cannot do to instill in youth a knowledge of and the respect for their religious heritage.

\subsection{Released Time for Religious Instruction}

After World War I especially, cooperation between public schools and representative churches was common to the extent that a designated amount of time per week was allotted for religious instruction. This went unchallenged because most parents desired to have their children instructed periodically in the religious tenets of their choice. By parental permission, children attended religious instruction during the school day, within the school building, taught by members of the clergy or religious order. The only cooperation the public school offered in addition to releasing children was the use of a room during the school day for a designated time per week, usually about an hour. Released time was a popular program.

This kind of religious program was challenged after World War II in Champaign County, Illinois, on the grounds that such a program established religion and was in violation of the First and Fourteenth Amendments. A Champaign Council on Religious Education was formed on a voluntary basis to handle all of the administrative and instructional details to circumvent the hazard of involving the public school in an unconstitutional manner; however, the problem was not avoided.

In McCollum v. board of Education (1948), the U.S. Supreme court decided it was clear that the use of the building $\mathrm{s}$ for religious instruction during the school day violated the First and Fourteenth Amendments. A tax-supported public school system was used to help religious groups indoctrinate children. McCollum wanted her son to receive only a secular education (nonreligious education) during the compulsory school day. Released time during this compulsory period for religious instruction, in her view, was sectarian (religious) indoctrination and consequently unconstitutional. The Court concurred.

The upshot of this case was a shock to many school boards and parents. What had been traditional was not banned during the school day. An alternative approach was attempted in the New York City School District 
whereby children could receive religious instruction during the school day, but off the premises. The school board offered a program so that parents interested in sending their school-age children to churches of their choice for religious instruction during a designated time each week could do so by returning a permission slip to their respective schools. The children, in turn, were transported at parental expense to nearby churches, which then sent back to the home school an attendance report. Children not interested in religious instruction would remain in school for a study or library period. There was no coercion from the school to get children to participate in religious instruction.

The U.S. Supreme Court in Zorach v. Clauson believed that this alternative approach to what was banned in McCollum met the constitutional text because no establishment of religion took place. In fact, the majority opinion held that when the state "cooperates with religious authorities by adjusting the schedule of public events to sectarian needs, it follows the best of our traditions". The difference between the McCollum and Zorach cases lay in the phrases "within the building" and "off the premises". In Zorach, the children participated constitutionally in religious instruction off the premises. It should be noted that states can participant in the kind of religious program advocated by the court in 1952 only if their respective constitutions allow such cooperation.

The Zorach decision has met with considerable controversy. Some critics have argued that the language in the majority opinion, such as that previously cited, can set a dangerous precedent because such cooperation may have no limit. The wall of separation could crumble. On the other hand, some proponents of nonpublic aid believe that if states cooperate in this manner, parents might be more satisfied with the public school. Sectarian instruction can be given off the property one hour a week, or one school day a month, or by some mutually arranged time during the compulsory school period. Also, religious instruction could be coordinated with social service to make it even more attractive to parents and students.

Parental interest in released-time programs over the years has lessened as a result of an exodus of families to suburban communities. Sidewalks are rare and churches are farther apart. Hence, transporting children to churches or center, often at private expense, becomes more difficult. Coupled with this problem is a diminished zeal on the part of many parents to send their children to church or to religious instruction at all, no matter how convenient. But, if a state constitution allows released-time programs to exist, school districts may cooperate with churches in this regard on a voluntary basis.

\subsection{Prayer and Bible Reading}

The next few cases cited in this part have elicited more reaction in the two decades following their appearance than most cases have on any topic. Parents, school boards, and politicians have taken sides on the emotional issues which emanated from these decisions. The Supreme Court has been involved with religious issues that have a direct lineage to those of over twenty years ago.

The first case that had a powerful impact upon the public school curriculum, and that is still referred to quite often, is Engel v. Vitale. The case developed as a result of a supposedly harmless prayer composed by the New York State Board of Regents and recommended to school districts across the state. It reads: Almighty God, we acknowledge our dependence upon Thee, and we beg Thy blessings upon us, our parents, and our country.

In the Union Free School District, New York, each class recited this prayer in the presence of the teacher at the beginning of every school day. The view of the Board Regents was that all people of good will could subscribe to the views in the above prayer. Parents often pupils, however, believed a school-sponsored prayer like that composed by the Board of Regents violated the First and Fourteenth Amendments. They believed it was religious activity. The court agreed and prohibited a secular agency such as the board of regents. A state department, or a school board from composing a prayer, no matter how "brief or general" it might be.

What this case did not answer was the question about student-initiated prayer, or even the question about meditation, which has since been a court issue, the idea of school sponsorship or religious activities is what infringes upon the doctrine of separation. This brings in the establishment principle; the case elicited much animosity toward the court on the part of citizens who thought it had rendered the schools godless. This case was to be the first of the three controversial decisions.

In the following year, companion cases aroused public opinion and literally sent schools on a new academic path concerning the place of religion in the public school. Parental written request could excuse children from these exercises.

The Schempp parents were Unitarian and did not care to have their two children exposed to a literal reading 
of the Bible, which ran counter to their religious beliefs. Readings were normally made without comment from the King James, the Douay, and the Revised Standard versions of the Bible.

\section{Aid to Nonpublic Schools}

In the second part of this article, we will overview to help the prospective teacher better understand the delicate relationship between church and state in relation to so-called fringe benefits to nonpublic schools. Benefits, such as secular textbooks and transportation assistance, are of vital concern to some religious groups. Representative forms of such aid will be discussed by reviewing what the U.S. Supreme Court has approved over the last several decades.

The term "nonpublic or private schools" covers a number of religious and independent institutions. In terms of the number of students in such institutions, the enrollment as of 1983 reached 5.7 million students, or 12.6 percent of the total 1983 public and private school enrollment. Private school, in this context, means that it is an institution embracing levels through grade twelve and is not a "home" school. It must meet at least four hours or more per day, 160 days a year. Preschools without a first grade are not considered in this enrollment.

The trends which these data on private school enrollment indicate are somewhat surprising. First, private education is assuming a greater role in schooling below the college level. Second, Catholic private education continues to be the largest of the private enrollment, but its numbers are shrinking while other affiliated and non-affiliated schools are increasing in enrollment. Catholic enrollment totaled 3.2 million students in 1983, a drop of approximately 200,000 students in a three-year period. Other private schools, however, have grown from about 2 million to 2.6 million students in the same three-year period. Catholic school enrollment below the college level as a percentage of total private school enrollment from 1980 to 1983 dropped from 64 percent to 56 percent while other private school enrollment increased by about 30 percent.

\subsection{Right of Choice}

The U.S. Supreme Court in 1925 rendered an opinion which has since been a judicial cornerstone for private education. In 1647 the Puritans assumed that parents had a choice in the type of school they desired for their offspring as long as certain competencies were attained. That belief continues to this day; however, at times it has been challenged.

In Oregon shortly after the close of World War I, a Compulsory Education Act was adopted by the voters, which in essence compelled children between ages eight and sixteen to attend public schools only. Exceptions to this law were made for special children, for children already finished with the eighth grade, for children geographically distant from a public school, and for the children already exempted by the Court because of special permits.

The act would have destroyed private education in Oregon by abrogating the parents' right to choose the school they desired for their offspring. The Court found the intent of this act very harmful. Consequently, parents in Oregon, as a result of this 1925 Supreme Court decision, pierce v. Society of the Sisters of the Holy Names of Jesus and Mary and Pierce v. Hill Military Academy, could continue to select nonpublic schools for their children.

\subsection{Units}

Following this famous 1925 Supreme Court decision, fringe benefit issues began to wend their way to the high Court. It now became even more acceptable to some people that if parents have the constitutional right to choose their child's school, then perhaps it is the state's duty to help them exercise that choice by means of selected secular benefits. The first celebrated case in this area was Cochran v. Louisiana State of Board of Education (1930). Louisiana believed that assisting any child in a private, parochial, or public elementary or secondary school was the prerogative of the state if that assistance meant support to the student to obtain a secular education during those years of compulsory education. Louisiana believed that providing secular textbooks met the constitutional test of neutrality. Textbooks could be evaluated in terms of sectarian influence or bias.

Cochran believed this state attitude violated the First and Fourteenth Amendments because nonpublic schools exist by choice and should be supported only by those who attend them. It was unreasonable, in his view, to use tax money to help those students, even if for secular purposes. 
The Supreme Court disagreed, however. It believed the child benefited rather than the institution, an attitude which became known as the "child benefit theory". This assumption later undergirded veteran educational benefits in that the individual can pursue educational activities in private or public institutions. The assistance is to the person not to the school. The "child benefit theory" still stands and has blossomed in many states in terms of selected fringe benefits, especially secular textbook assistance. The state must allow such aid by authority of its constitution, and them there must be a willingness by the state legislature or department to assist students in all schools below the college level.

\subsection{Transportation}

In a major case decided in 1947, the U.S. Supreme Court advanced the cause of assistance to nonpublic schools. In Everson v. Board of Education, the issue of transportation aid emerged in New Jersey. In Ewing Township there were no public or private high schools. It was agreed upon by state officials and parents that high school youth would utilize public transportation to and from Trenton, New Jersey, to attend the high schools of their choice. Parents, consequently, would be reimbursed with state funds for transportation costs only.

Everson contested the fact that parents of children in parochial schools were reimbursed for their transportation costs. According to Everson, this was an unreasonable use of public money. He believed only parents of students attending public schools should be eligible. The high Court disagreed, however, on the grounds that providing for the "general well-being" of a student has a constitutional basis irrespective of the school attended. To transport students, in other words, at state expense is promoting an element of safety during those years of compulsory schooling. This case allowed the states the choice to assist nonpublic students if their respective constitutions permitted such transportation assistance. The First and Fourteenth Amendments, the Court believed, were not violated in this particular context.

\subsection{Federal Programs}

A Supreme Court case decided in 1968 involved a federal program in public and private schools. In the Board of Education, the issue of lending secular textbooks purchased with federal funds under the sponsorship of the then Title II Elementary and Secondary Education Act was contested because parochial schools were involved. Both the First and the Fourteenth Amendments were in question because of the establishment principle. This case was important because had the loaning of secular textbooks been voided by the Court, one of the most important federal educational programs of all time would have been greatly diluted.

The Court decreed that it could not see any violation of the establishment principle in the matter of loaning secular textbooks. The law did not interfere with religious instruction in the parochial school. The Court further stated that it could not accept the argument that secular textbooks would become instruments to teach religion in the parochial schools. It believed that sectarian schools also have a secular purpose, which they have demonstrated for a long time. Consequently, the use of these textbooks would further only a secular mission.

\section{Conclusion}

Religion in relation to public education has two components: one deals with the theme of religious content in the curriculum and the other concerns fringe benefits to nonpublic schools. The U.S. Supreme Court in its several decisions concerning religious content in the public school curriculum has taken a positive stance. The Court has struck down ritualized, religious activities in the school, such as Bible reading, the recitation of the Lord's Prayer and school sponsored nondenominational prayer. The Court, however, has urged public schools to teach about religion in an academic context. The religious heritage is important; the Court believes that no student's education, in fact, is complete without an understanding of the religious heritage. The second component, concerning religion and public education, deals with fringe benefits to nonpublic schools. Given the present political mood of the nation, religion in relation to public education will continue to be a topic of keen interest.

\section{References}

[1] Arval, A.M. (1974) The Constitution and American Education. West Publishing Co., St. Paul.

[2] Leo, P. (1953) Church, State, and Freedom. The Beacon Press, Boston. 
[3] Edgar, W.K. and Clifton, L.H., Eds. (1951) Readings in American Educational History. Appleton-Century-Crofts, New York.

[4] Lawrence, A.C. (1957) The Republic and the School: Horace Mann on the Education of Free Men. Teachers College Press, New York. 
Scientific Research Publishing (SCIRP) is one of the largest Open Access journal publishers. It is currently publishing more than 200 open access, online, peer-reviewed journals covering a wide range of academic disciplines. SCIRP serves the worldwide academic communities and contributes to the progress and application of science with its publication.

Other selected journals from SCIRP are listed as below. Submit your manuscript to us via either submit@scirp.org or Online Submission Portal.
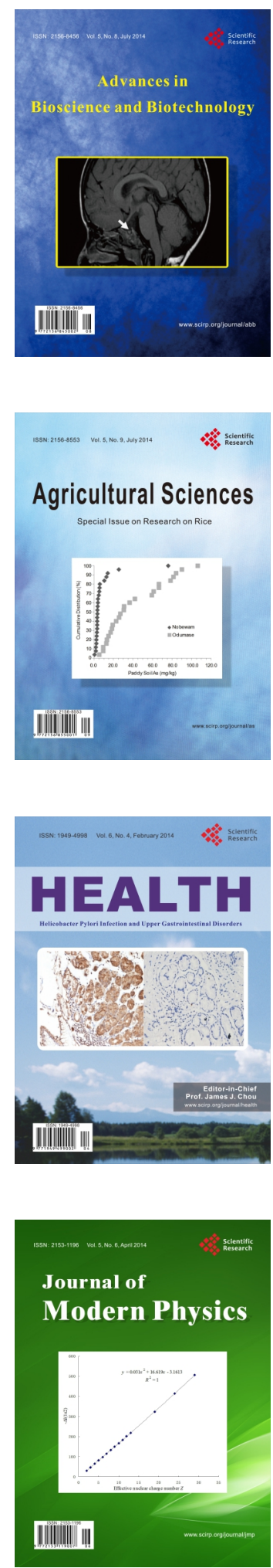
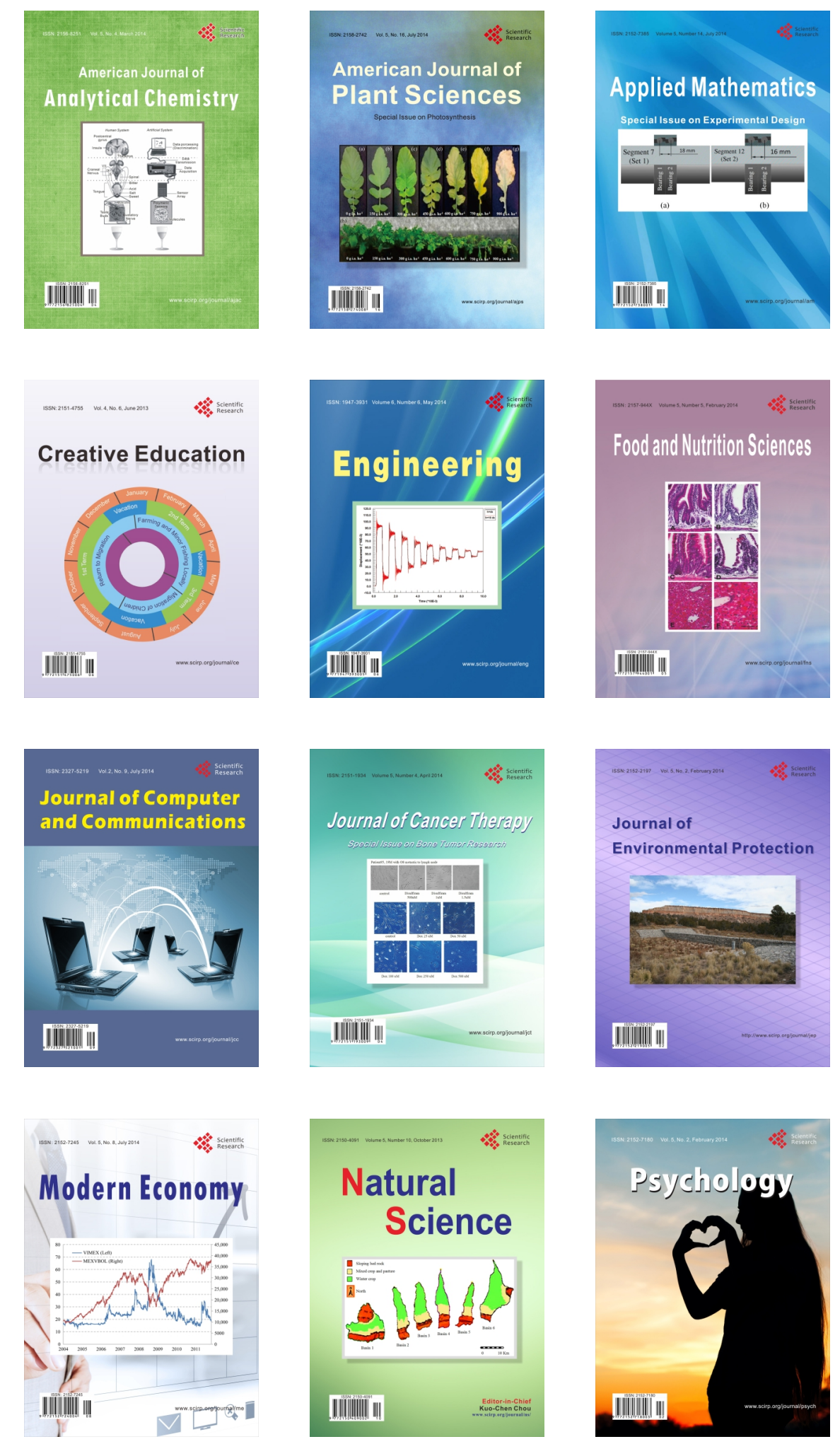